\title{
SPECIAL NEEDS OF ENTREPRENEURS WITH DISABILITIES IN THE CONDITION OF THE REPUBLIC OF MOLDOVA
}

\author{
Elena ACULAI', PhD, Associate Professor, \\ National Institute for Economic Research, Republic of Moldova \\ Lilia SAGHIN², PhD Student, \\ National Institute for Economic Research, Republic of Moldova
}

\author{
DOI: https://doi.org/10.36004/nier.es.2020.1-03 \\ JEL Classification: I24, J71, L26, L38 \\ UDC: 334.72(478)
}

\section{ABSTRACT}

People with disabilities experience significant difficulties in the process of finding a job, which is caused not only by their health status, difficulty in getting education, but also by the reluctance of entrepreneurs to hire disabled people. In this situation, people with disabilities, who can provide selfemployment or create their own business, get an additional chance to have a constant source of income, develop themselves and, in general, integrate more successfully into social life. The aim of the research was to identify the basic needs of support of entrepreneurs with disabilities; for this purpose, in 2017, a survey of 75 individuals was conducted. The results of the survey implemented within the project of the National Institute for Economic Research (NIER) showed that for people with disabilities (unlike other groups of small entrepreneurs) is not enough to create a favorable business environment. No less important is the improvement of general living conditions of persons with disabilities, especially the improvement of their access to social infrastructure, education and the labor market. The main directions of the state support of people with disabilities aimed at the business development and selfemployment, are proposed to be following: improvement of legislation on supporting social entrepreneurship to increase the ability of persons with disabilities to be employed; improvement of access to education for people with disabilities through building and modernization of social infrastructure objects; use of direct economic and financial forms of support for this group of people, including through state target programs; support for the establishment of business associations uniting entrepreneurs with disabilities, etc.

Keywords: small and medium-sized enterprises, people with disabilities, entrepreneurs with disabilities, need for support of entrepreneurs, state support for entrepreneurs with disabilities.

Persoanele cu dizabilități întâmpină dificultăți semnificative în procesul de găsire a unui loc de muncă, ceea ce este cauzat nu doar de starea lor de sănătate și dificultățile întâmpinate în procesul educațional, dar și de reticența antreprenorilor de a angaja persoane cu dizabilități. În această situație, persoanele cu dizabilități, care se pot asigura cu muncă independentă sau își pot crea propria afacere, au șansa suplimentară de a avea o sursă constantă de venit, de a se realiza și, în general, de a se integra cu succes în viața socială. Scopul cercetării a fost identificarea necesităților de bază de sprijin ale antreprenorilor cu dizabilități, în acest scop în a.2017 a fost realizat un sondaj care a cuprins 75 de persoane. Rezultatele sondajului realizat în cadrul unui proiect implementat de Institutul Național de Cercetări Economice (INCE) au arătat că pentru persoanele cu dizabilități (spre deosebire de alte grupuri de întreprinzători mici), crearea unui mediu de afaceri favorabil nu este suficientă. La fel de importantă este și îmbunătățirea condițiilor generale de viață, printre care prioritate a fost acordată îmbunătățirii accesului persoanelor cu dizabilități la infrastructura socială, educație și piața muncii. Principalele direcții ale sprijinului de stat pentru persoanele cu dizabilități ce au drept scop dezvoltarea antreprenoriatului și a activității independente, includ: îmbunătățirea legislației și sprijinirea

1 (C) Elena ACULAI, $\$ eaculai@yandex.com

2(C) Lilia SAGHIN, $₫$ lilia.saghin@gmail.com 
antreprenoriatului social pentru creșterea capacității persoanelor cu dizabilități de a se angaja; îmbunătățirea accesului la educație pentru persoanele cu dizabilități, inclusiv prin construirea și modernizarea obiectelor de infrastructură socială; utilizarea unor forme economice și financiare directe de sprijin pentru acest grup de persoane, inclusiv prin programe vizate de stat; sprijin pentru formarea asociațiilor de afaceri care unesc antreprenorii cu dizabilități etc.

Cuvinte-cheie: întreprinderi mici și mijlocii, persoane cu dizabilități, antreprenori cu dizabilități, necesități de sprijin ale antreprenorilor, sprijin de stat pentru antreprenori cu dizabilități.

Лица с инвалидностью испытывают существенные сложности в процессе поиска работы, что обусловлено не только состоянием их здоровья, сложностью получения образования, но и нежеланием предпринимателей брать на работу инвалидов. В сложившейся ситуации люди с инвалидностью, которые могут обеспечить самозанятость или создать собственный бизнес, получают дополнительный шанс иметь постоянный источник дохода, реализовать себя и, в целом, более успешно интегрироваться в социальную жизнь. Целью исследования являлось выявление основных потребностей предпринимателей $c$ инвалидностью в поддержке, для чего в 20172. был проведен опрос 75 респондентов. Результаты опроса, реализованного в рамках проекта Национального института экономических исследований (НИЭИ), продемонстрировали, что для лиц с инвалидностью (в отличие от других групп мелких предпринимателей), недостаточно создание благоприятной бизнес-среды. Не менее важным является улучшение общих условий жизни, приоритетными среди которых оказалось улучшение доступам инвалидов к объектам социальной инфраструктуры, образованию и рынку труда. К основным направлениям государственной поддержки лиц с инвалидностью., направленным на развитие предпринимательства и самозанятости, предлагается отнести: совершенствование законодательства и поддержка социального предпринимательства для повышение возможности лиц с инвалидностью получить занятость; улучшение доступа лиц с инвалидностью к системе образования, в том числе путем строительства и модернизации объектов социальной инфраструктуры; использование прямых экономических и финансовых форм поддержки указанной группы лиц, в том числе посредством государственных целевых программ; поддержка формирования бизнес-ассоциаций, объединяющих предпринимателей с инвалидностью и др.

Ключевые слова: малые и средние предприятия, лица с инвалидностью, предприниматели с инвалидностью, потребности предпринимателей в поддержке, государственная поддержка предпринимателей с инвалидностью.

\section{INTRODUCTION}

Today, social and economic integration of people with disabilities represents one of the international priorities, especially after the adoption of the Convention on the Rights of Persons with Disabilities in 2006. The Convention was signed by all EU Member States and more than 100 other countries of the world, including the Republic of Moldova. The Convention obliges the states that have ratified this document to ensure that persons with disabilities have the opportunity, on an equal basis with other citizens, to fully enjoy their rights, including access to education, employment, transport, infrastructure and buildings opened for public access, increase participation in political life, etc.

In the economic developed countries, people with disabilities are involved in the labor field and work in all the types of activities, but, however in other countries they often remain inactive on the labor market. So, statistics of the European Union testify that, for example, in Austria only $22 \%$ of the identified population with disabilities are not active on the labor market, while in Poland this indicator reaches $78 \%$. This variation can be explained by several factors, including the extent to which persons with disabilities are included or excluded from education, discrimination of employers, demographic factors, etc. [OECD 2014].

In the Republic of Moldova, 180.6 thousand people (i.e. more than $5 \%$ of the total population of the country) are persons with disabilities, many of whom cannot find employment on the labor market; one of the reasons of this is that employers are not interested in employing them. In this 
situation, development of their own business provides an additional opportunity for people with disabilities to ensure a decent standard of living and social integration. However, for the active involvement of persons with disabilities in the business, the support from the government is needed more than for other small entrepreneurs. The scientific hypothesis of the study is that it is not enough for people with disabilities, unlike for other groups of small entrepreneurs, to provide favorable conditions for business development: the improvement of their general living conditions is equally important as well.

In order to identify the basic needs of entrepreneurs with disabilities, a survey has been carried out with the active participation of authors. The survey included not only entrepreneurs/selfemployed, but also individuals, who intend to set up their own businesses in the next 1-2 years. The survey was conducted by NIER in the framework of the applied research project 15.817.06.05A "Harmonizing the SMEs development policy in the Republic of Moldova with the principles of the "Small Business Act" for Europe"; stage of 2017: "Improving the SMEs Support Policy in the Republic of Moldova: Improving the Opportunities for Development of Entrepreneurs from the Socially Vulnerable Categories of the Population", with the support of the Association of Entrepreneurs with Disabilities of the Republic of Moldova [Aculai 2017].

REVIEW OF THE SCIENTIFIC LITERATURE ON THE BUSINESS ACTIVITIES OF PERSONS

\section{WITH DISABILITIES}

In the last decades, the lives of people with disabilities are studied by institutions aimed at developing and promoting inclusive policies and eliminate stereotypes present in the society. To a large extent, the research deals with the involvement of disabled people in active work. Labor activity is considered as necessary not just for having a decent living, but it also fulfills a number of basic human needs including those with a social purpose, status and professional activity, which help to support mental health and well-being. For people with disabilities, work is a matter of special importance because having a disability often means being socially isolated. The work represents an opportunity to reduce this isolation [UN 2007].

To date, not many studies regarding the problems and needs of entrepreneurs with disabilities have been published. Nevertheless, self-employment and entrepreneurship can be used as a potential means of professional rehabilitation, in order to achieve a faster and better integration into the labor market and, eventually, social inclusion [8]. Data on the activities of persons with disabilities are limited. Available information suggests that among this group, people are more often unemployed or inactive. At the same time, employed people are often hired on low qualification working places with low salaries [Meager, Higgins 2011].

According to one of the leading researchers of entrepreneurs with disabilities J. Kitching, people with a disability face many specific obstacles in the process of initiating and sustaining entrepreneurship, partly because of poor education, low employment rates and concentration of employees with disabilities in low-paid activities [Kitching 2014]. Scientific papers include, among the barriers faced by people with disabilities, the following: limited access to the start-up capital and lack of knowledge and skills specific to the business; [Foster 2010]; lack of adequate support [Boylan, Burchardt 2002] etc. However, in the modern specialized literature, disability is not regarded as an insurmountable obstacle in carrying out entrepreneurial activity or barrier to participation on the labor market. On the contrary, it is assumed that the advantages of entrepreneurship for people with disabilities can far outweigh any risk involved. Being a disabled entrepreneur allows achieving professional and personal goals and could lead to a higher level of job satisfaction [Győri1 et al. 2019].

Often, entrepreneurial activity is a forced one for persons with disabilities, which affects its content. The reason for becoming an entrepreneur or self-employed person is mostly an incentive that results from a constraint or fear of something (e.g. unemployment or discrimination) that creates a completely different situation than if entrepreneurship is based on an independent decision [8]. However, in other cases, the motivation of people with disabilities to pursue independent activities results from the positive reasons, such as the desire for independence, passion for entrepreneurship and the innovative pursuit of opportunities [Drakopoulou, Keles 2015].

Successful stories are significant enough to motivate people with disabilities, especially if they describe the own experiences of people who have achieved great results. In particular, professor 
Stephen W. Hawking believes that: "Disability should not represent an obstacle to success. I have suffered virtually all my adult life from motor neuron disease. However, this has not prevented me from having a wonderful career in astrophysics and having a happy family life" [OMS 2012].

Support policies for persons with disabilities are implemented both nationally and internationally. Thus, the World Report on Disability suggests measures for all stakeholders governments, civil society organizations and organizations of persons with disabilities - to create enabling environments, develop recovery and support services, provide adequate social protection, create programs and inclusive policies and the implementation of new and existing standards and legislation for the benefit of people with disabilities. People with disabilities should be in the center of these concerns [OMS 2012].

Brief quantitative characteristics of persons with disabilities in the Republic of Moldova

In the Republic of Moldova, according to statistical data of 2017, the total number of persons with disabilities amounted to 180.6 thousand people. However, access to the labor market is limited, as the participation rate of persons with disabilities constituted $19.7 \%$ compared to $49.2 \%$ for persons without disabilities. Among the men with disabilities, the activity rate was $20.3 \%$, and for women $-19.0 \%$. In the urban area, the participation rate accounted for $16.8 \%$ and in the rural area $21.5 \%$. Unemployment rate (as defined by the International Labor Office) of persons with disabilities was $2.9 \%$ compared to $4.1 \%$ among unemployed people without disabilities.

The employment rate of persons with disabilities is lower compared to that of persons without disabilities: while the employment rate of persons without disabilities is $47.2 \%$, among persons with disabilities this constitutes only $19.1 \%$. In men, this indicator registered $19.7 \%$, in women, respectively, $18.5 \%$. The employment rate of people with disabilities in rural areas was higher (21.1\%) compared to that in urban areas $(16.0 \%)$.

Of the total number of employed persons with disabilities, the employees make up $46.8 \%$ (compared to $65.7 \%$ for persons without disabilities). The share of self-employed persons constitutes $44.0 \%$ (in agriculture $38.7 \%$ and in non-agricultural activities $5.3 \%$ ), involved in the family activities as unpaid worker are integrated $8.6 \%$ and only $0.6 \%$ have the status of business owner.

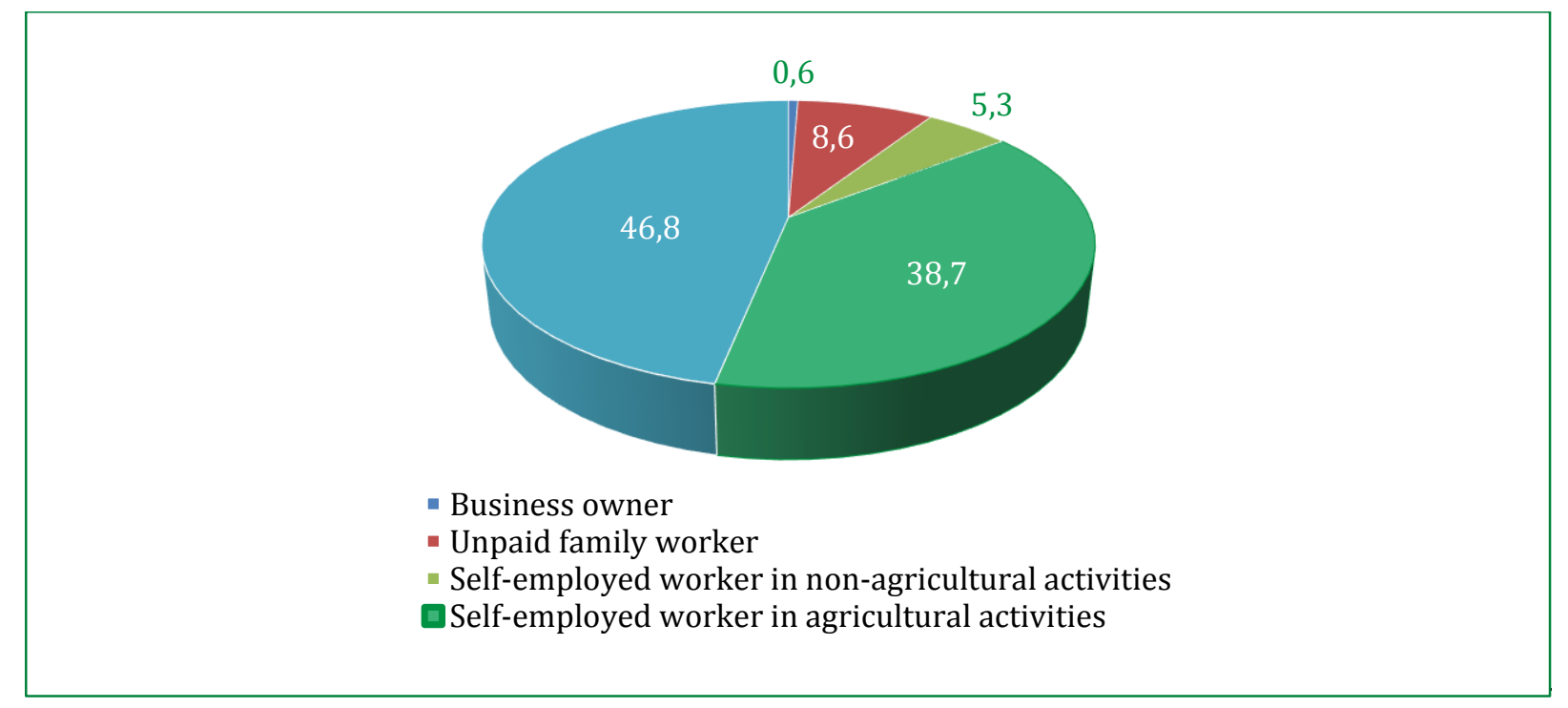

Figure 1. Structure of occupied persons with disabilities by professional status, $2017, \%$ Source: National Bureau of Statistics [NBS 2018].

According to the Activity report of the National Agency for Employment in 2018, about 623 persons with disabilities were registered with unemployment status. Out of the total number of unemployed people with disabilities, 260 people (42\%) are women. According to the age categories of persons with disabilities with unemployed status, 22\% persons are aged between 16-29 years, $37 \%$ - between $50-62$ years and $41 \%$ - between $30-49$ years. 


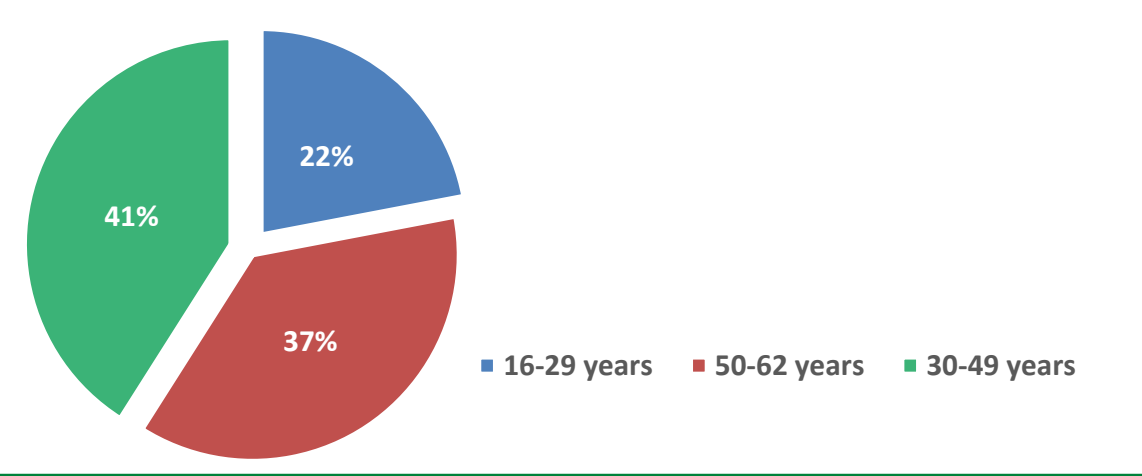

Figure 2. Age category of persons with disabilities registered with unemployed status, $2018, \%$ Source: NAE activity report 2018 [NBS 2018].

Qualifications of the personnel with disabilities recorded by NAE are the following:

- 51\% persons with primary/secondary / high school education;

- $25 \%$ persons with secondary-professional education;

- $24 \%$ persons with college/university studies;

Thus, it can be mentioned that the highest share is made up by people with average qualifications, mainly primary / secondary / high school studies, which makes access to the labor market difficult and makes them more susceptible to unskilled and poorly paid work.

During 2018, 356 persons with disabilities benefited from work intermediation services, at the same time 58 people were integrated in vocational training courses, and 65 persons were involved in public works. 275 persons were successfully placed in the field of work, while $44 \%$ of the total number of persons with disabilities were registered with unemployed status.

It is important to emphasize on the small number of persons in the records of the National Agency for Employment; if statistically the number of persons with disabilities is of the order of tens of thousands, then the number of the persons in the register as unemployed are of the order of hundreds. This gap between the persons in the NAE records and the real one results in a low degree of employment and lack of training, as well as vocational reorientation courses.

In the Republic of Moldova, the substantiation of the policies for inclusion of persons with disabilities on the labor market are regulated by the provisions of the Law on the social inclusion of persons with disabilities. Thus, art. 34 paragraph (4) assumes that "employers, regardless of the form of legal organization, which according to the scheme of hiring staff have 20 or more employees, create or reserve jobs and employ persons with disabilities in a percentage of at least $5 \%$ of the total number of employees" [LEGIS 2012].

Although the present law indicates that in case of failure to comply with these provisions during a financial year the employers are sanctioned according to the Contraventional Code, these sanctions are missing in the legislation and are not applied. Gaps in the legislation allow employers to take advantage of and not implement the legislative provisions.

In regard to entrepreneurial activity, it is not formalized in any way for people with disabilities, although at the legislative level, there are no restrictions or barriers that could slow down the process of developing the entrepreneurial activities carried out by people with disabilities. At the same time, the law on entrepreneurship and enterprises does not provide measures to support entrepreneurs with disabilities, because it favors stagnation of the current state of economic and social exclusion of persons with disabilities [LEGIS 1992].

The business environment as well as the civil society show a reluctance in the process of inclusion of persons with disabilities. This low receptivity prevails because the employment of persons with disabilities is mainly performed in specialized companies that are in a very small number, and are located in a restricted area, satisfying the need for jobs, thus creating barriers for both entrepreneurs and people with special needs. Therefore, the most pressing problem remains not the lack of means of integration in the economic activities, but the fact that the society and entrepreneurs have set certain unwritten limits, so very few people have overcome these barriers.

The main factor hindering the process of integrating people with disabilities into economic activities, 
at the same time as entrepreneurship, is the lack of statistical data on the number, structure of entrepreneurs and self-employed workers, which accentuates the inefficiency of some economic integration programs, because the lack of data on the number of beneficiaries and their needs cannot be estimated without their actual knowledge.

Special needs of entrepreneurs with disabilities in the conditions of the Republic of Moldova (based on survey results)

Methods and sources of information used. Sample feature

For a more detailed identification of the needs of persons with disabilities involved in entrepreneurial activities or intending to create their own business in the next 2 years, a survey was conducted as part of the NIER project [7] with the support of the Association of Entrepreneurs with Disabilities from the Republic of Moldova during May - September 2017. This study of entrepreneurs with disabilities is the first one in the Republic of Moldova, based on original primary information.

The sample consisted of 75 persons. The main characteristics of the sample are as follows:

- Out of the total number of respondents, $49.3 \%$ of people have the entrepreneur status, respectively $50.7 \%$ of people are potential entrepreneurs.

- Respondents refer to age categories of 25-35 years (50.7\%) and 36-50 years (49.3\%).

- Respondents domiciled in the urban area make $67.6 \%$ of the total number of people surveyed, in the rural area $-32.4 \%$.

- The main areas of activity chosen by entrepreneurs with disabilities are: services area - $70.3 \%$ of enterprises, trade $-16.2 \%$ of enterprises and agriculture $-5.4 \%$ of enterprises.

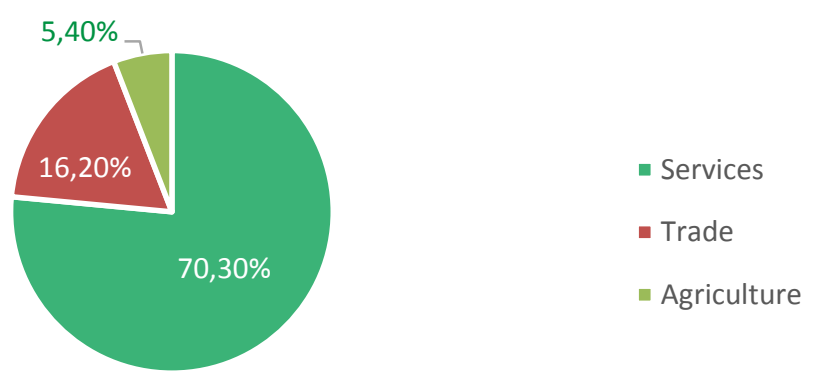

Figure 3. Areas of activity of entrepreneurs with disabilities

Source: Outcomes of the survey [Aculai 2017].

Respondents are characterized by different degrees of disability. Out of the total number of surveyed persons, $72 \%$ have the degree of severe disability (1st degree), $24 \%$ - pronounced degree of disability (group II) and 4\% - the average degree of disability (group III). Thus, we can conclude that the degree of severe or pronounced disability does not represent an invincible impediment in order to the conduct an entrepreneurial activity.

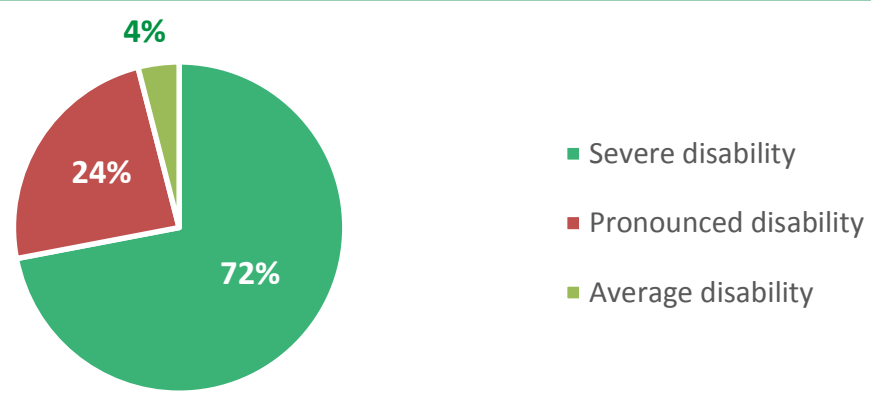

Figure 4. Disability degree of the surveyed persons

Source: Outcomes of the survey [Aculai 2017].

No. $1 / 2020$ 
To carry out any activity, it is necessary to have a certain level of professional training. Although success in business is not directly related to the availability of special education, but in the conditions of the Republic Moldova (as well as a number of other countries with emerging market economies), most entrepreneurs have higher or secondary specialized education. This characteristic fully applies to the surveyed group of people: $61.3 \%$ of the respondents have a higher level of education, $18.7 \%$ have professional and secondary education, $20.0 \%$ - have high school and gymnasium education.

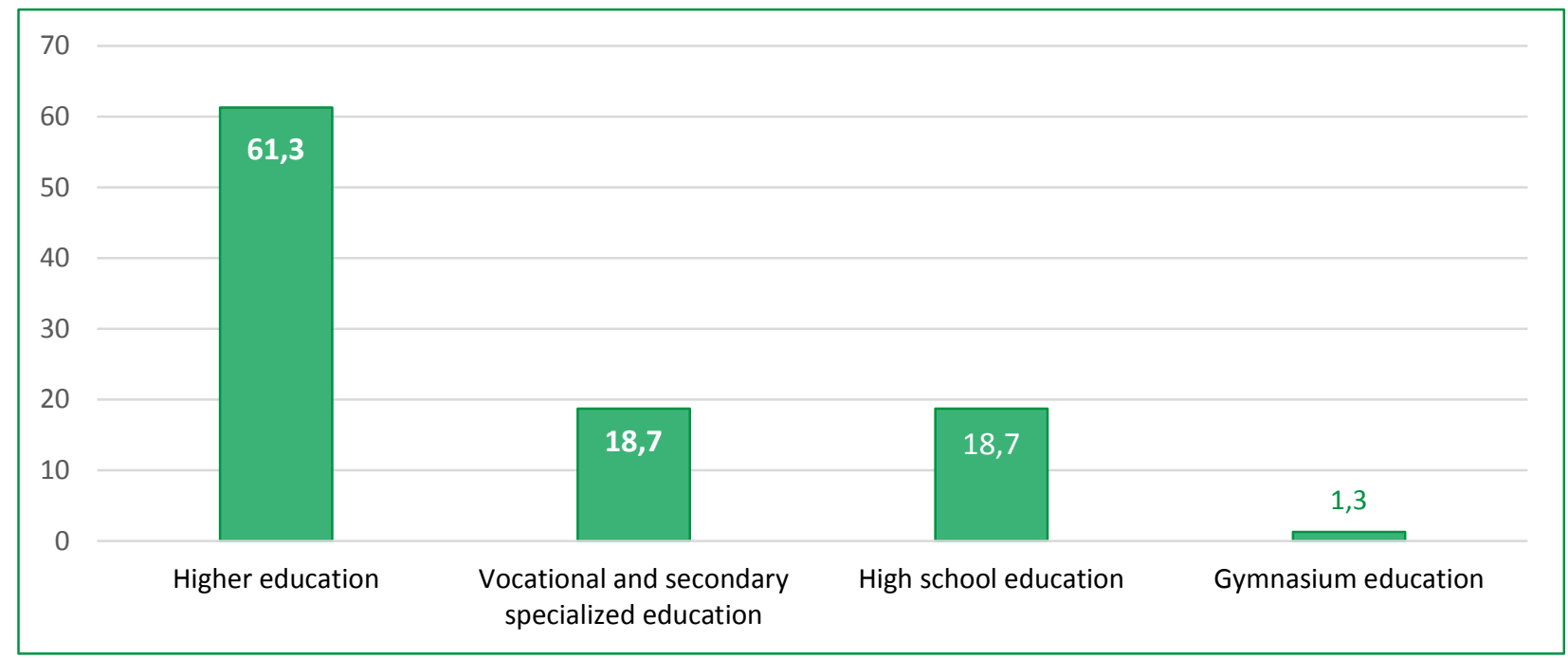

Figure 5. Professional training of questioned persons with disabilities

Source: Outcomes of the survey [Aculai 2017].

Despite the fact that $80 \%$ of respondents have specialized education, many of them have a business profile not related to acquired knowledge. Thus, only for $38.9 \%$ of the respondents the professional education corresponds to the profile of the held business, and for $61.1 \%$ of them the owned business does not correspond with the obtained studies.

The success of a business depends not only on education, but also on previous experience. More than $2 / 3$ of those surveyed have previous work experience, but this is mainly experience as an employee, not an entrepreneur. So, $2.7 \%$ of the respondents have experience as a business owner, $68.0 \%$ - have the employee status and $29.3 \%$ of the respondents have no previous work experience.

Most of the respondents had no business experience and management experience as well. In particular, of the total number of respondents, who at the time of completing the questionnaire were carrying out entrepreneurial activities, only $2.7 \%$ indicated that they previously had management experience, respectively $97.3 \%$ did not have such experience when they decided to set up their own business.

Needs of entrepreneurs with disabilities for state support

In order to develop the entrepreneurial activity carried out by people with disabilities, according to the respondents, it is necessary to support their businesses by the state. In this purpose it is advisable to use various directions and measures for improving the business environment.

Respondents identified the following main paths, which would increase the chances of setting up and developing the business: use of direct methods of economic / financial state support; improve training opportunities for entrepreneurs and potential entrepreneurs; support for the establishment and development of business associations; improve the attitude of entrepreneurs with disabilities to business support organizations, including public authorities. As the survey showed, all of the above mentioned areas and measures have a very high priority for respondents. In particular, $100.0 \%$ of respondents indicated the importance of such measures as: development of a state target program, which will provide for preferential financing of the entrepreneurial activity of people with disabilities; 
providing tax and payment facilities for this group of entrepreneurs; improving the possibilities of acquiring knowledge in the field of entrepreneurship; supporting the activity of business associations and improving the attitude of state officials, other business support organizations.

The set of answers reflecting the need for state support with regard to improving the conditions for the development of business among persons with disabilities is presented in the table 1.

Table 1

The need for support from the state with regard to improving the conditions for the development of businesses among persons with disabilities* Types of support

\begin{tabular}{|l|c|}
\hline \multicolumn{1}{|c|}{ Direct economic and financial forms of support } & $\%$ \\
\hline $\begin{array}{l}\text { Development of a state target program, which provides for preferential financing } \\
\text { of the entrepreneurial activity of persons with disabilities at the stage of starting } \\
\text { the business }\end{array}$ & 100,0 \\
\hline $\begin{array}{l}\text { Provision of tax and payment facilities for this group of entrepreneurs (for example, } \\
\text { exemption from payment of insurance rates or facilities for payment of communal } \\
\text { services for business) }\end{array}$ & 100,0 \\
\hline \multicolumn{1}{|c|}{ Improving learning opportunity } & 100,0 \\
\hline $\begin{array}{l}\text { Improving the possibilities for acquiring knowledge in the field of } \\
\text { entrepreneurship, taking into account the different degrees of work capacity and } \\
\text { the limitations on types of activities }\end{array}$ & \\
\hline Developing a mentoring system at the start-up stage & 98,6 \\
\hline \multicolumn{1}{|c|}{ Support for the establishment and development of business associations } \\
\hline $\begin{array}{l}\text { Supporting the activity of business associations, which mainly meet or include } \\
\text { entrepreneurs from persons with disabilities (including, involving their leaders in } \\
\text { the activity of the Advisory Councils near the public administration bodies) }\end{array}$ & 100,0 \\
\hline $\begin{array}{l}\text { Strengthening the partnership with other business associations, in order to jointly } \\
\text { promote the interests of different groups of entrepreneurs }\end{array}$ & 98,6 \\
\hline $\begin{array}{l}\text { Improving relations to entrepreneurs with disabilities } \\
\text { business support organizations towards entrepreneurs among people with } \\
\text { disabilities }\end{array}$ & 100,0 \\
\hline
\end{tabular}

${ }^{*}$ Respondents had the opportunity to give multiple answers.

Source: Outcomes of the survey [Aculai 2017].

At the same time, the results of the survey clearly demonstrated that in order to increase the possibilities of developing the businesses set up and managed by people with disabilities, it is not enough to create a general favorable business environment. It is necessary to improve the general living conditions for this group of entrepreneurs. In particular, respondents believe that they need diverse forms of support, associated primarily with the solution of medical and domestic problems, education, employment on the labor market, adaptation of social infrastructure and sociopsychological factors.

The highest priority is given to such forms of support as:

- design, construction and modernization of social infrastructure objects $(100.0 \%$ of respondents);

- improving the possibilities for obtaining general and professional studies (100\%);

- supporting social entrepreneurship oriented towards increasing the employment of people with disabilities and production of goods / services necessary for them (98.6);

- changing the attitude of the society towards people with disabilities (95.9\%), etc.

It is significant that, according to respondents, government assistance in solving medical and domestic problems is slightly less significant than problems associated with access of persons with disabilities to social infrastructure, education and the labor market. 
Table 2

The need for state support, with reference to improving the general living conditions of people with disabilities*

Related to the adaptation of social infrastructure objects

and social objects, etc.), in order to make them more accessible (existence of ramps, etc.)

\section{Related to receiving of education}

Improving the possibilities for obtaining general and professional studies (home education and training, internet training possibilities, etc.)

\section{Related to the provision of employment on the labor market}

Supporting social entrepreneurship oriented towards increasing the employment of people with disabilities and production of goods / services necessary for them

Creation of job places and special conditions for employment

Improving professional rehabilitation, as well as social integration

Associated with socio-psychological factors

Changing society's attitude towards people with disabilities (more confidence, a

welcoming environment, etc.)

Promoting the positive image, disseminating success stories of entrepreneurs among people with disabilities

\section{Related to the solution of medical and domestic problems}

Provision with articles and specialized means of rehabilitation, which allow people with disabilities to be involved in work and social activity (ocular prostheses, hearing aids, typhotechnical means, optical means, etc.).

Improvement of the system of expertise and determination of the degree of invalidity

Improving health care, rehabilitation and home treatment

Improving the system of providing social care and personal assistance in solving problems at home

${ }^{*}$ Respondents had the opportunity to give multiple answers

Source: Outcomes of the survey [Aculai 2017].

Needs of entrepreneurs with disabilities for suport from business associations

Another form of support for entrepreneurs with disabilities may be business associations. Survey results demonstrated that cooperation, exchange of practices and other forms of collaboration between entrepreneurs (without taking into account sales relations) are characteristic for the majority of respondents: out of the total number of respondents engaged in entrepreneurship, 70.3\% cooperate with other entrepreneurs and $29.7 \%$ entrepreneurs do not have any cooperative relations.

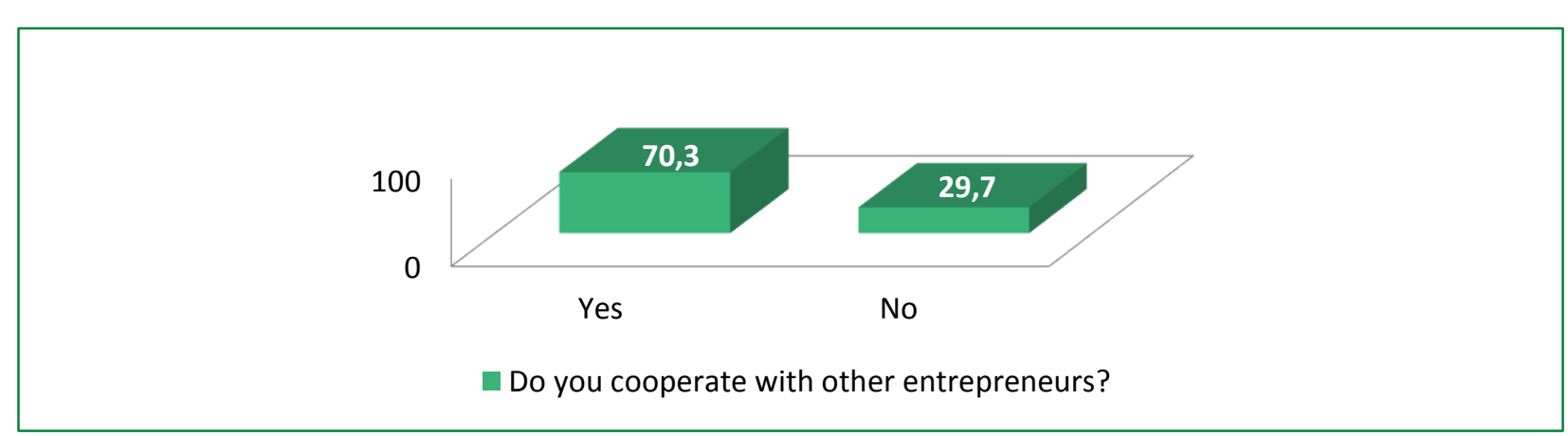

Figure 6. Cooperation relations of entrepreneurs with disabilities, $\%$ Source: Outcomes of the survey [Aculai 2017]. 
Entrepreneurs with special needs are looking for different ways to become more efficient in the business environment through their own powers and initiatives, while through business associations is aimed at creating opportunities for collaboration for these members with other third parties. Out of the surveyed entrepreneurs with disabilities, $45.9 \%$ people are members of business association, $37.8 \%$ - not members, and $16.3 \%$ people plan to join a business association starting next year.

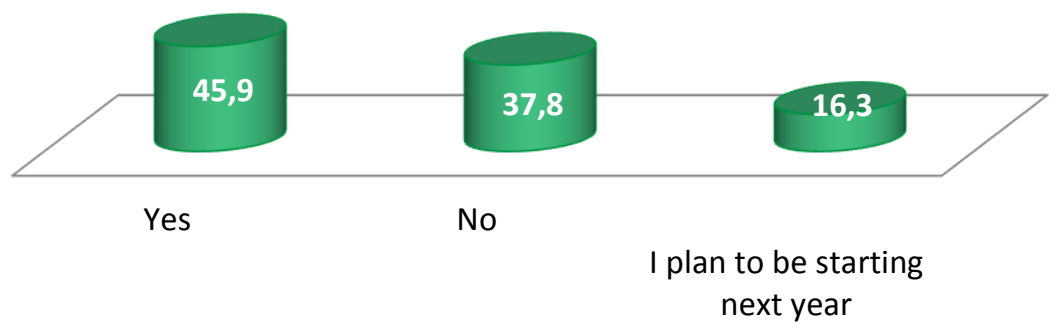

Figure 7. Membership of entrepreneurs with disabilities in business associations, \% Source: Outcomes of the survey [Aculai 2017].

Almost all $100 \%$ of respondents who are members of business associations indicated that they benefited from within business associations with:

- useful information;

- possibility to participate in training courses;

- support in establishing contacts with other companies;

- possibility to get involved in the implementation of joint projects;

- support in protection and promotion of their interests in public administration bodies.

A significant share of members of business associations received consultancy services $(94,1 \%)$, as well as psychological and emotional support (88,2\%).

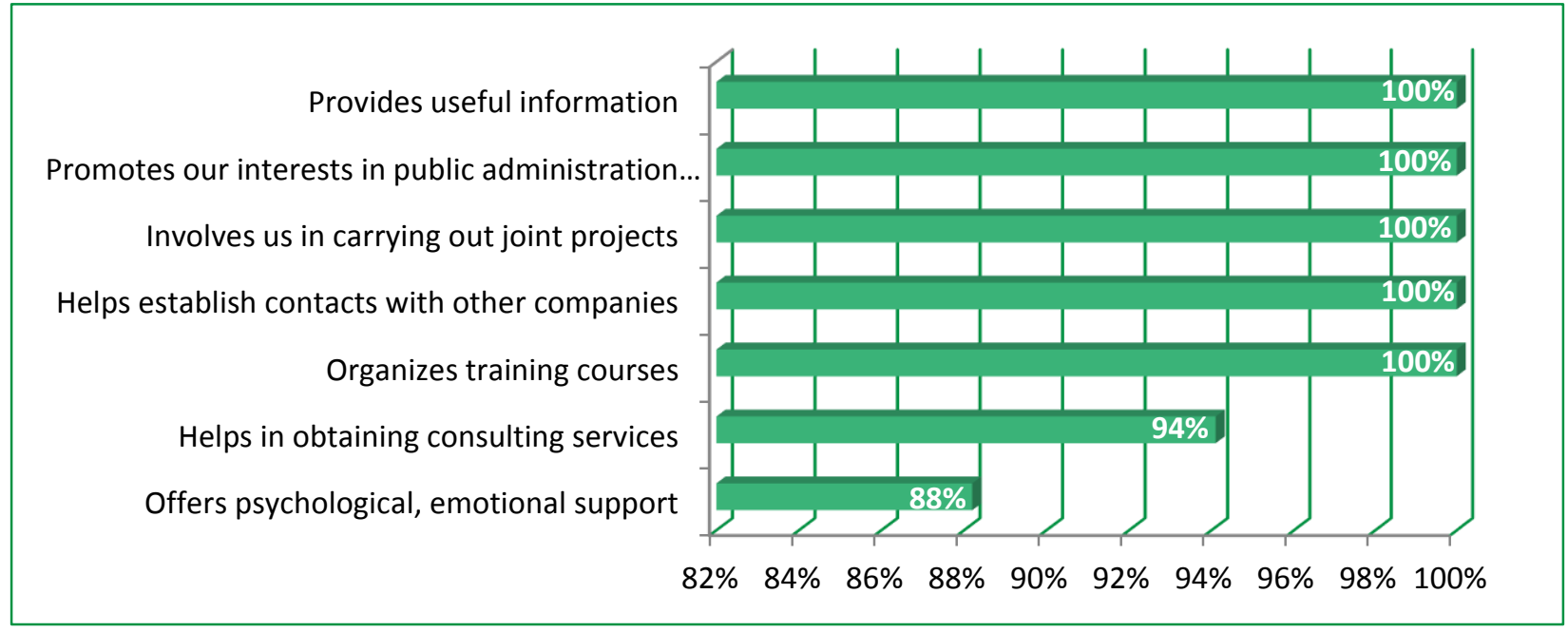

Figure 8. Services offered by the business association*

* Respondents had the opportunity to give multiple answers

Source: Outcomes of the survey [Aculai 2017].

In order to improve the activity of business associations $100 \%$ of respondents consider that it is necessary to promote the successes of the associations more actively and the state should improve the financial possibilities of the associations. For $78.4 \%$ of respondents it is important to improve the quality of the services offered by the business associations. 
The state should improve the financial possibilities of the associations

It is important to promote the successes of associations more actively

It is important to improve the quality of services offered by business associations

Entrepreneurs should be more active

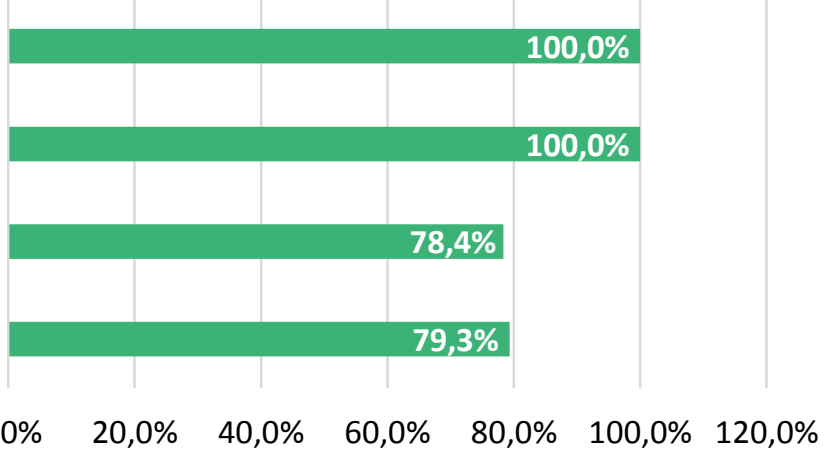

$0,0 \% \quad 20,0 \% \quad 40,0 \% \quad 60,0 \% \quad 80,0 \% \quad 100,0 \% \quad 120,0 \%$

Figure 9. Ways to improve the activity of business associations*

* Respondents had the opportunity to give multiple answers

Source: Outcomes of the survey [Aculai 2017].

\section{MAIN CONCLUSIONS}

The support policy of entrepreneurs from underprivileged groups and those underrepresented in business should take into account the specifics of their activities, special problems and needs for support. In the Republic of Moldova, the entrepreneurial activity of persons with disabilities has not been investigated yet. This study is the first one, based on primary information, i.e. the results of surveys.

The analysis of the results made it possible to establish areas of the state support for people with disabilities.

First of all, it is necessary to provide a differentiated entrepreneurship support system, which varies significantly with respect to certain groups of disadvantaged population and those underrepresented in business, including entrepreneurs with disabilities.

One of the important tasks is to increase the opportunity of persons with disabilities to obtain employment on the labor market by improving legislation, monitoring its implementation and supporting social entrepreneurship.

Equally significant is improvement of the access of people with disabilities to the education system, including through construction and modernization of social infrastructure objects, to make them more convenient for people with special needs.

Other expected measures include use of direct economic and financial forms of support for this group of people, including through state targeted programs; improvement of the system of assistance to persons with disabilities in solving domestic and medical (including psychological) problems; support the establishment and consolidation of business associations that unite entrepreneurs with disabilities or are aimed, inter alia, at working with them.

Finally, it is advisable to actively promote in society the idea of real opportunities for people with disabilities to create their own business, as an alternative to finding a job on the labor market. This represents an additional chance to increase their material level and self-accomplishment.

\section{REFERENCES}

1. AGENŢIA NAŢIONALĂ PENTRU OCUPAREA FORȚEI DE MUNCĂ. Raport de activitate pentru anul 2018. Chişinău, 2019 [citat 21 februarie 2020]. Disponibil: http://anofm.md/files/elfinder/ Raportul\%20activit.\%20ANOFM\%202018\%20final\%20word\%20Terzi.docx

2. BIROUL NAȚIONAL DE STATISTICĂ AL REPUBLICII MOLDOVA. Persoanele cu dizabilităţi în Republica Moldova în anul 2017 Chişinău, 2018 [citat 10 martie 2020]. Disponibil: https://statistica.gov.md/newsview.php?l=ro\&idc=168\&id=6191

3. BOYLAN, A., BURCHARDT, T. Barriers to Self-Employment for Disabled People: Report for the Small Business Service. 2002, october. 98 p. [citat 23 ianuarie 2020]. Disponibil: https://webarchive.nationalarchives.gov.uk/20090609014837/http://www.berr.gov.uk/files/file383 57.pdf 
4. DRAKOPOULOU DODD, S., KELES, J. Expanding the networks of disadvantaged entrepreneurs. A background paper for the OECD Centre for Entrepreneurship, SMEs and Local Development. 2015. 46 p. [citat 10 martie 2020]. Disponibil:

https://www.oecd.org/cfe/leed/Expanding\%20the\%20networks\%20of\%20disadvantaged\%20entre preneurs.pdf

5. FOSTER, S. Promoting Entrepreneurship Among Disabled People with Visual Impairment. RNS. 2010, july. 51 p. [citat 18 martie 2020]. Disponibil:

https://www.google.com/url?sa=t\&source=web\&rct=j\&url=https://www.heacademy.ac.uk/system/fil es/hwlln_promoting_entrepreneurship_visual_impairment.pdf\&ved=2ahUKEwjn39Somv7oAhUL3qQK HRV0CKcQFjAFegQIAhAB\&usg=AOvVaw2_wHwCnK46gg_8-ZILMqEu\&cshid=1587633512625

6. GYŐRI1, Z., SVASTICS, C., CSILLAG, S. Push and Pull Motivations of Entrepreneurs With Disabilities in Hungary. Zagreb, 2019 [citat 16 martie 2020]. Disponibil: https://www.econstor.eu/bitstream/10419/196093/1/ofel-2019-p351-366.pdf

7. ACULAI, Elena. Armonizarea politicii de dezvoltare a IMM-urilor în Republica Moldova cu principiile "Small Business Act" pentru Europa". Etapa a. 2017: Perfecţionarea politicii de susţinere a IMM-urilor în Republica Moldova: îmbunătăţirea posibilităţilor pentru dezvoltarea antreprenorilor din categoriile social-vulnerabile ale populației. INCE. Chișinău, 2017.78 p.

8. KITCHING, Jonh. Entrepreneurship and Self-Employment by people with Disabilities. Background Paper for the OECD Project on Inclusive Entrepreneurship. Kingston University. Kingston, 2014, september.

28 p. [citat 11 februarie 2020]. Disponibil: https://www.researchgate.net/profile/John_Kitching/publication/266137166_Entrepreneurship_and_ self-employment_by_people_with_disabilities/links/544293c10cf2a76a3ccb020b/Entrepreneurshipand-self-employment-by-people-with-disabilities.pdf

9. Legea Republicii Moldova cu privire la antreprenoriat și întreprinderi: nr. 845 din 03.01.1992. In: Monitorul Parlamentului. 1994, nr. 2, art. 33 [citat 10 ianuarie 2020]. Disponibil: https://www.legis.md/cautare/getResults?doc_id=17094\&lang=ro

10.Legea Republicii Moldova privind încluziunea socială a persoanelor cu dizabilități: nr. 60 din 30.03.2012. In: Monitorul Oficial al Republicii Moldova. 2012, nr. 155-159, art. 508 [citat 04 martie 2020]. Disponibil: https://www.legis.md/cautare/getResults?doc_id=83915\&lang=ro

11.MEAGER, N., HIGGINS, T. Disability and Skills in a Changing Economy. Briefing Paper Series. Institute for Employment Studies. UK Commission for Employment and Skills. 2011 [citat 10 martie 2020]. Disponibil: https://www.employment-studies.co.uk/resource/disability-and-skills-changing-economy

12.0ECD. Policy Brief on Entrepreneurship for People with Disabilities. Entrepreneurial Activities in Europe. 2014. ISBN 978-92-79-33519-8 [citat 12 februarie 2020]. Disponibil: http://www.oecd.org/cfe/leed/Policy-brief-entrepreneurship-people-disabilities.pdf

13.ORGANIZAȚIA MONDIALĂ A SĂNĂTĂȚII. Raport mondial privind dizabilitatea. București, 2012. 319 p. ISBN 978-973-0-13597-8 [citat 10 martie 2020]. Disponibil: https://apps.who.int/iris/bitstream/handle/10665/44575/9789730135978_rum.pdf;jsessionid=6EB 4DE67B81F4E324F60DB285BCEFDA4?sequence $=20$

14.UNITED NATIONS. Convention on the Rights of Persons with Disabilities [A/RES/61/106]. 2007, january [citat 17 ianuarie 2020]. Disponibil: https://www.un.org/development/desa/disabilities/resources/general-assembly/convention-on-therights-of-persons-with-disabilities-ares61106.html

15.VORNHOLT, K., UITDEWILLIGEN, S., NIJHUIS, F. Factors Affecting the Acceptance of People with Disabilities at Work: A Literature Review. In: Journal of Occupational Rehabilitation. 2013, vol. 23, no. 1, march. ISSN 1573-3688 [citat 12 ianuarie 2020]. Disponibil: https://www.researchgate.net/publication/235522864_Factors_Affecting_the_Acceptance_of_People_ with_Disabilities_at_Work_A_Literature_Review

\section{ARTICLE HISTORY}

Received 23 March2020

Accepted 28 April 2020 